\title{
Characterizing an outperforming pea cultivar for intercropping with oat at high latitudes
}

\author{
Pirjo Peltonen-Sainio ${ }^{1}$, Markku Kontturi², Antti Laine ${ }^{2}$, Markku Niskanen $^{3}$, Timo Hurme ${ }^{2}$, Lauri Jauhiainen ${ }^{2}$ \\ ${ }^{1}$ Natural Resources Institute Finland (Luke), Latokartanonkaari 9, FI-00790 Helsinki, Finland \\ ${ }^{2}$ Natural Resources Institute Finland (Luke), FI-31600 Jokioinen, Finland \\ ${ }^{3}$ Natural Resources Institute Finland (Luke), FI-61400 Ylistaro, Finland \\ e-mail: pirjo.peltonen-sainio@luke.fi
}

\begin{abstract}
The cereal often dominates the grain legume in intercrops, especially when sown in larger amounts. This study assessed yield formation of pea (Pisum sativum L.) and oat (Avena sativa L.) in an intercropping system in high-latitude conditions. Three pea cultivars (Hulda, Karita and Perttu) and one oat cultivar (Roope) were grown as sole crops and intercrops with shares of either $7.5 \%$ or $15 \%$ of oat (as weight of sown seed mixture). Experiments were organized in three (southern, western and northern) locations of Finland for three years. Yield and vegetative above-ground biomass, their land equivalent ratio (LER, i.e., the yield in intercrop compared to that of the component yields in pure stands), and a number of yield components were measured prior to harvest at crop-stand and single-plant levels. The share of oat in the intercrop did not have any impact on variation in LER $_{\text {yield }}$. Oat yield and yield components generally benefitted from a pea companion crop. The pea cultivar Perttu was superior in intercrops: it had $a L R_{\text {vield }}>1$ in seven out of eight experiments (mean LER $R_{\text {vield }}=1.06$ ), while Karita had a LER vield $>1$ in four (mean LERvield $=1.00$ ) and Hulda only in one experiment (mean $L_{E R}$ vield $=0.98$ ). Perttu proved to be a compatible pea companion for a pea-oat intercrop, likely because it was successful in overcompensating for decline in relative yield (RGY) of oat in intercrops, contrary to Hulda. However, none of the measured yield components of Perttu were associated with LER $_{\text {yield }}$ suggesting compensation ability between them, while in Karita and Hulda, e.g., higher grain yield and number of grains and pods per square meter were associated with decline in LER $\mathrm{v}_{\text {vield }}$. It was concluded that the success of Perttu as a companion for oat in intercrops is likely attributable to its flexibility in building yield through a variable combination of yield components rather than being outperformed due to some superior traits. Such flexibility, likely attributable to long duration of flowering supports resilience to weather variability that is typical for northern European conditions allowing Perttu to consistently sustain $\operatorname{LER}_{\text {yield }}>1$.
\end{abstract}

Key words: cultivar, grain, growing conditions, intercrop, land equivalent ratio (LER), oat, pea, yield

\section{Introduction}

Grain legumes provide many valuable ecosystem services for agriculture, which supports the aim to expand their cultivation and explore their potential for development of more sustainable agricultural systems. They provide the means to diversify cropping systems that are currently dominated by cereal monocultures in Finland (Peltonen-Sainio et al. 2017) and benefit from nitrogen (N) fixation capacity. These and many other ecosystem services provided by grain legumes may lead to a decrease in dependency on fossil fuel-consuming input use, increase in production of crop-based protein and long-term improvements in resilience against climatic variability through diversified cropping systems in high-latitude conditions (Peltonen-Sainio et al. 2016a). Designing agricultural systems that benefit from multi-functionality and better balanced agronomic and environmental services is a means to maintain viable and sustainable food production (Storkey et al. 2015). Thereby, expanding the introduction of leguminous crops to crop rotations supports processes aiming to sustainably intensify European agricultural systems (Soussana et al. 2012) - also in high-latitude conditions.

Pea (Pisum sativum L.) is a minor crop in Finland, which was cultivated on some 12000 hectares in 2015 (corresponding to $0.5 \%$ of cultivated area), of which 2700 hectares were organic (www.stat.luke.fi/en). However, due to the warming climate-induced potential for longer growing seasons and subsequent higher yields, an expansion of pea cultivation from its current minor and regionally localized production is appealing (Peltonen-Sainio et al. 2009, Peltonen-Sainio et al. 2013). In general, pea exhibits high variation in yield and quality at high latitudes. Both abiotic and biotic constraints negatively affect yield stability. Intercropping with cereals is often a feasible means to increase yield stability in pea, e.g. through preventing lodging (Kontturi et al. 2011, Podgórska-Lesiak and Sobkowicz 2013) and having less disease outbreaks (Schoeny et al. 2010). Furthermore, the use of legume companions in intercrops enhances suppression of weed growth without reducing crop yields (Verret et al. 2017). 
Regionally, localized pea cropping may, however, further increase risks for pest infestation, especially if cultivation expands within or near prime production regions (Huusela-Veistola and Jauhiainen 2006). In the case of strongly localized production, intercrops may again offer a means to alleviate risks.

Intercropping often increases yield stability, as it expresses many benefits compared to pea monocropping as a result of complementarities between the companion crops. However, intercropping makes the anticipation of yield shares of companion crops uncertain and may challenge the use of harvested yield, e.g., as on-farm feed (Kontturi et al. 2011), even though techniques for separation of peas and cereals have developed. Hence, many studies have focused on improving our understanding of the contribution of crop phenological timing and growth dynamics to competition, growth performance and yield formation processes between species in intercrops (Hauggaard-Nielsen et al. 2006, Barker and Dennett 2013, Monzon et al. 2014, Brooker et al. 2015).

The aim of this study was to assess the differences between pea cultivars in Land Equivalent Ratio for grain yield $\left(\right.$ LER $\left._{\text {yield }}\right)$ when intercropped with oat and to understand the reasons for the different performance of pea cultivars in intercrops. As earlier studies have indicated that the choice of pea cultivars in intercrops is more critical than that of cereal cultivars (Hauggaard-Nielsen and Jensen 2001), three pea cultivars - differing in growth characteristics - were selected for this study to find a compatible candidate exhibiting consistently high LER yield $_{\text {in }}$ high latitude conditions. Oat (Avena sativa L.) was selected to be the cereal companion as results from Estonia (Lauk and Lauk 2008) have emphasized that particularly oat as a companion crop in intercrops with pea was superior, especially when aiming for high grain and protein yield production capacities.

\section{Materials and methods \\ Experimental arrangements}

Field experiments were arranged in three geographically representative locations in Finland: Jokioinen $\left(60^{\circ} 49^{\prime} \mathrm{N}\right.$, $\left.23^{\circ} 03^{\prime} \mathrm{E}\right)$, Mietoinen $\left(60^{\circ} 37^{\prime} \mathrm{N}, 21^{\circ} 51^{\prime} \mathrm{E}\right)$ and Ylistaro $\left(62^{\circ} 56^{\prime} \mathrm{N}, 22^{\circ} 29^{\prime} \mathrm{E}\right)$ during the period $2002-2004$. In 2004 the experiment in Ylistaro was, however, abandoned due to heavy lodging and major problems with sampling, crop separation and yield component measurement. Hence, the total number of experiments that were analyzed was eight. The soil types were heavy clay in Jokioinen, very fine sand and silty clay in Mietoinen, and sandy gyttja clay in Ylistaro. Additional information about soil conditions has been published earlier (Kontturi et al. 2011). Daily weather data was made available for all the experimental sites by the Finnish Meteorological Institute.

Field experiments were organized in completely randomized block designs with four replicates. Three different semi-leafless afila-types (af gene transforming the leaflets into tendrils [Cousin 1997]) and intermediate-height pea cultivars were grown as pure stands and in intercrops with oat. As the growing season is very short in Finland, only sufficiently adapted pea cultivars were included in experiments. The Karita pea cultivar, released by SvalöfWeibull, is the most popular green-grained pea cultivar grown in Finland (23.9\% of pea area in 2014). Another green-grained cultivar Hulda is currently the third most popular pea cultivar (18.7\%), while the yellow-grained Perttu (both cultivars from Boreal Plant Breeding Ltd) is especially designed for intercropping. Sensitivity to lodging differs according to Official Variety Trials: Karita is the most lodge-resistant (28\% mean lodged area) followed by Hulda (41\%) and Perttu (73\%). The lodging sensitivity in the Perttu cultivar was also apparent in this study (Kontturi et al. 2011). The oat cultivar Roope was selected as a companion crop as it is an early maturing, lodgeresistant cultivar by Boreal Plant Breeding.

Oat (500 seeds $\mathrm{m}^{-2}$ ) and pea (140 seeds $\mathrm{m}^{-2}$ ) were grown as pure stands and with $7.5 \%$ or $15 \%$ of oat (as weight of planting seed) in a mixture with pea. As the seed weight of pea cultivars differs (for Karita $274 \mathrm{mg}$, Hulda 241 $\mathrm{mg}$ and Perttu $238 \mathrm{mg}$ ), seeding ratios were harmonized according to the pea cultivar Perttu and corresponded thereby to 130 pea and 67 oat or 120 pea and 133 oat seeds per square meter, respectively. Seeds were sown simultaneously in the same row, hence, we applied replacement design for this study (Snaydon 1991). However, as the pure stands of pea and oat differ markedly in number of seeds per square meter, the replacement was not fully equivalent in numbers of replaced seeds but the compensation was based on weight of seeds. Spatial arrangements of pea and oat plants in pure stands and intercrops are shown in Fig. 1. 
a)

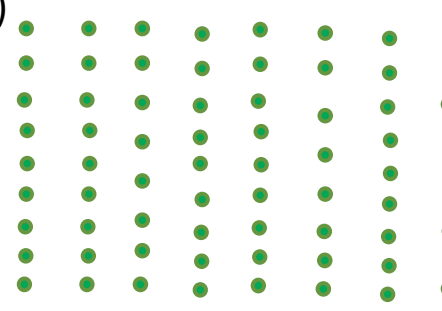

Pure stand of pea 140 seeds $\mathrm{m}^{-2}$ b)

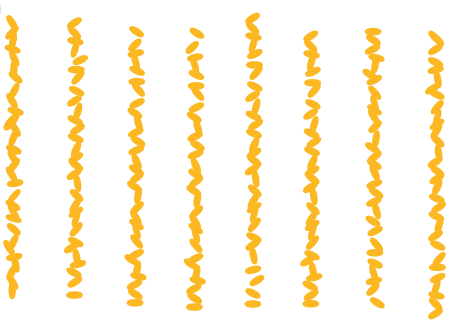

Pure stand of oat 500 seeds $\mathrm{m}^{-2}$ c)

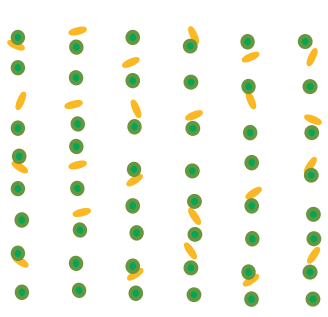

Replacement mixture: pea 130 and oat 67 seeds $\mathrm{m}^{-2}$

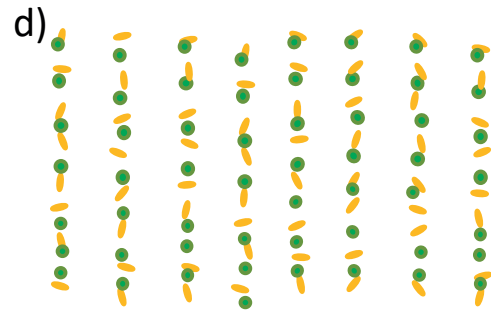

Replacement mixture: pea 120 and oat 133 seeds $\mathrm{m}^{-2}$

Fig. 1. Replacement design used for pea-oat intercropping experiments with pure pea (a) and oat stands (b), an intercrop with $7.5 \%$ (c) and $15 \%$ oat seed (d). The seeds were sown simultaneously in the same row.

Pure stands and intercrops were grown in $1.25 \times 10 \mathrm{~m}$ plots. The pure stand of oat was fertilized with $90 \mathrm{~kg} \mathrm{~N} \mathrm{ha}^{-1}$, while pure stands of pea cultivars and pea-oat intercrops were fertilized with $30 \mathrm{~kg} \mathrm{~N} \mathrm{ha}^{-1}$. The fertilizer included phosphorus ( $18 \mathrm{~kg} \mathrm{ha}^{-1}$ for oat and $4-6 \mathrm{~kg} \mathrm{ha}^{-1}$ for pea), potassium (48 kg ha-1 for oat and 7-16 kg ha-1 for pea) and all essential micronutrients. The nutrient content varied slightly depending on the experiment and according to soil nutrient content and soil type (Kontturi et al. 2011). The lower $\mathrm{N}$ rate in intercrops was used to facilitate the general success of pea as an $\mathrm{N}$-fixing companion (Hauggaard-Nielsen and Jensen 2001). As the often-recorded dominance of a cereal crop over grain legumes is demonstrated to be attributable to faster cereal root growth enhanced by $\mathrm{N}$ availability (Corre-Hellou et al. 2007), only a low amount of starter- $\mathrm{N}$ was supplied to intercrops to diminish the potential dominance of oat over pea. Weeds were controlled with herbicides containing bentazon as the active ingredient, while diseases and pests were controlled according to need.

Plant-stand establishment was monitored by seedling counting $(5 \times 1 \mathrm{~m}$ row). Onset, duration and end of pea flowering, as well as timing for panicle emergence in oat, were recorded. Crops were combine harvested and dried to $10-12 \%$ moisture content. Grain yield (GY, $\mathrm{g} \mathrm{m}^{-2}$ ) was weighed for each plot (shown at $15 \%$ moisture content) and shown separately for both companion crops and also as the joint total intercrop GY. Details on procedures are reported by Kontturi et al. (2011). To compare $\mathrm{N}$ content in a crop at harvest to applied $\mathrm{N}$ fertilizer $\left(\mathrm{N}_{\text {ratio }}\right), \mathrm{N}$ concentration (\%) in oat and pea grains was analyzed for all yield samples by using a Kjeltec System 1026 (Tecator 1987).

Before harvest, samples for yield component analyses were collected ( $5 \times 0.5 \mathrm{~m} \mathrm{row})$ and gently dried with a cold-air drier (outside temperature $\leq 25^{\circ} \mathrm{C}$ ) to a $\leq 14 \%$ moisture content. Plant samples from each plot and replicate were divided into oat and pea plants in the case of intercrops. The number of pea and oat plants per sample was counted and the total above-ground biomass weighed and transformed per land area ( $\mathrm{g} \mathrm{m}^{-2}$ ) and per plant $\left(\mathrm{g} \mathrm{plant}^{-1}\right)$ for both companion crops and as the joint total intercrop biomass. Vegetative biomass was weighted and transformed similarly after threshing seeds by hand. Yield advantage was calculated as LER yield (Willey 1990) by dividing yield in the intercrop by that in a pure stand separately for the pea and oat crop and summing them.

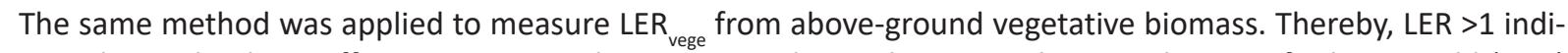
cates better land use efficiency compared to pure stands. Furthermore, the contribution of relative yield (RGY) and relative vegetative biomass yield (RVEGE) of companion crops to LER yield $_{\text {and } L E R_{\text {vege }}}$ was measured (Monzon et al. 2014), respectively. 
To characterize the compatibility of intercropped pea and oat at the population level, yield components were measured per unit land area (unit $\mathrm{m}^{-2}$ ), whereas to identify the changes in single plant architecture due to intercropping, the results were transformed per plant (unit plant ${ }^{-1}$ ). The following yield components were determined (both $\mathrm{m}^{-2}$ and plant ${ }^{-1}$ if not otherwise shown): for pea, number of pods and grains, number and weight of grains per pod $\left(\right.$ no. $\left.\operatorname{pod}^{-1}, \mathrm{~g} \mathrm{pod}^{-1}\right)$, grain yield $\left(\mathrm{g} \mathrm{plant}^{-1}, \mathrm{~g} \mathrm{pod}^{-1}\right.$ ) and single grain weight (mg); for oat, number and weight of grains and single grain weight (mg). Harvest index ( $\mathrm{HI}, \%)$ was determined by dividing the total weight of grains by total above-ground biomass and multiplied by one hundred.

\section{Statistical analyses}

A variance component model was fitted to the data to estimate the amount of variation in a dependent variable (LER $_{\text {yield }}$ or Intercropped GY) that is associated with other variables (pea cultivar, year, location, experiment, share of intercropping, replication within experiment). All effects are random and categorical in the model. This results in the relative importance of the factors: the model shows the proportion of variance attributable to each main and interaction effects. Variance components were estimated using the MIXED procedure of SAS version 9.3 and REML estimation method.

The GY, vegetative biomass, LER $_{\text {yield' }} L_{\text {Leg }}$ and yield component data, as well as $\mathrm{N}_{\text {ratio' }}$, were analyzed according to a statistical model (ANOVA) for the randomized complete block design with factorial treatment structure, based on pea cultivar and share of intercrop components over eight individual experiments from three seasons (2002-2004) at three different locations (one experiment was rejected). Before analyzing the data, graphical methods were used for individual observation of each trait to identify potential outliers. The erroneous records were excluded and the outcome of analyses with and without false observations was compared. Furthermore, some of the traits were carried through square root transformation prior to analyses to achieve Gaussian distribution. The linear mixed model was formulated as:

$$
y_{i j k l}=\mu+b_{i(j)}+e_{j}+c_{k}+p_{l}+(c \times p)_{k l}+(\operatorname{exc})_{j k}+(\exp )_{j l}+(\operatorname{excxp})_{j k l}+\varepsilon_{i j k l}
$$

where $\mu$ is constant and $e_{j^{\prime}} c_{k^{\prime}} p_{,}(c \times p)_{k l^{\prime}}(\operatorname{exc})_{j k^{\prime}}(\exp )_{j l}$ and $(\operatorname{exc} \times p)_{j k l}$ are fixed main and interaction effects for the experiment $(e)$, share of intercrop components $(c)$ and pea cultivar $(p)$. The $b_{i(j)}$ is the random effect for block $i$ (nested in experiment), and $\varepsilon_{i j k l}$ is the random error term, all mutually independent with variances $\operatorname{var}\left(b_{i(j)}\right)=\sigma_{b}^{2}$ and $\operatorname{var}\left(\varepsilon_{i j k l}\right)=\sigma_{\varepsilon}^{2}$, respectively (Petersen 1994).

For all the models mentioned above, REML was used as an estimation method and degrees of freedom were calculated by the Kenward-Roger method (Kenward and Roger 1997). The models were fitted using the MIXED procedure of SAS version 9.3 (SAS Institute, Cary, NC, USA). Pairwise comparisons were performed by two-sided t-type tests. The model assumptions were checked using appropriate graphs and tests.

\section{Results}

In total $38 \%$ of variation in LER $_{\text {yield }}$ was explained by variation caused by experimental variables, from which $43 \%$ was attributable to differences between cultivars in their responses to intercropping depending on year and location (pea cultivar $\times$ year $\times$ location). On the other hand, differences between pea cultivars were consistent from one experiment to another. As pea cultivars per se explained $10 \%$ of total variation in LER $_{\text {yield }}$, variation where pea cultivars were involved had a significant contribution of $53 \%$ to the total variation found for $L_{E R}$ yield Growing conditions contributed an additional $32 \%$ to the observed variation in $L_{E R}$ yield with the share of $22 \%$ for impact of year and $10 \%$ for location. The share of oat in the intercrop did not have any impact on variation in $\operatorname{LER}_{\text {yield }}(<1 \%)$, while $15 \%$ of variation was attributable to differences between replicates within an experiment. Figure 2 characterizes how highly variable weather conditions occurring during the study period (see also Suppl. Fig. S1) caused variation both in timing and duration of phenological events like flowering in pea, panicle emergence in oat, and maturation of plant stands, depending on pea cultivar, location and year. 

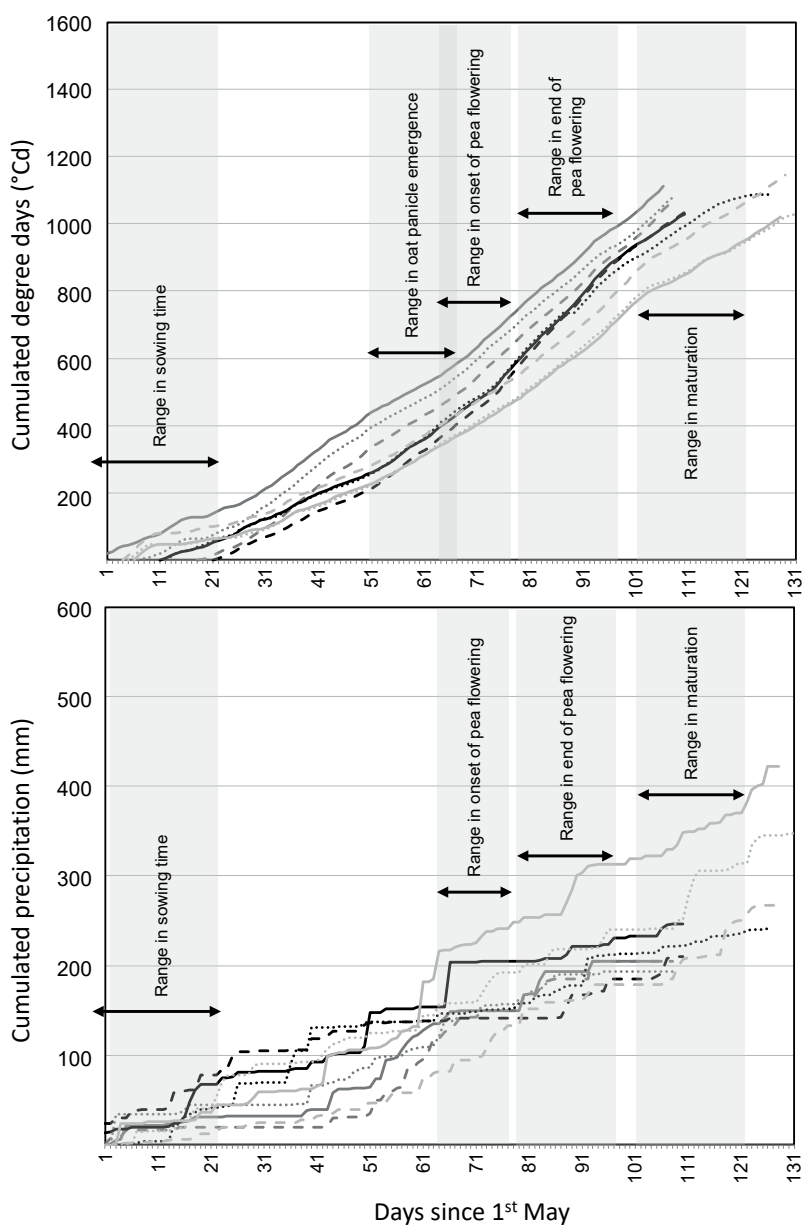

Fig. 2. Accumulation of degree days $\left({ }^{\circ} \mathrm{Cd}\right)$ and accumulation of precipitation $(\mathrm{mm})$ from sowing to harvest in 2002-2004 for the Jokioinen, Mietoinen and Ylistaro regions. Variation in timing of sowing, oat heading, onset and end of pea flowering and maturation of the whole plant stand are shown according to year, location and pea cultivar. Dark gray indicates accumulation of degree days and precipitation in year 2002, black 2003 and light gray 2004 and the solid line Jokioinen, the dashed line Mietoinen and the dotted line Ylistaro. The tail end of each line indicates the time of combine harvesting.

Pea cultivar $\times$ experiment interaction was significant for $\operatorname{LER}_{\text {yield }}(p=0.009)$. The pea cultivar Perttu was superior when intercropped with oat, as the LER $_{\text {yield }}$ was $>1$ in seven out of eight experiments (Fig. 3). For oat, RGY was always less than 0.5 , while only for the best performing pea cultivar, Perttu, the value exceeded 0.8 in a couple of experiments.
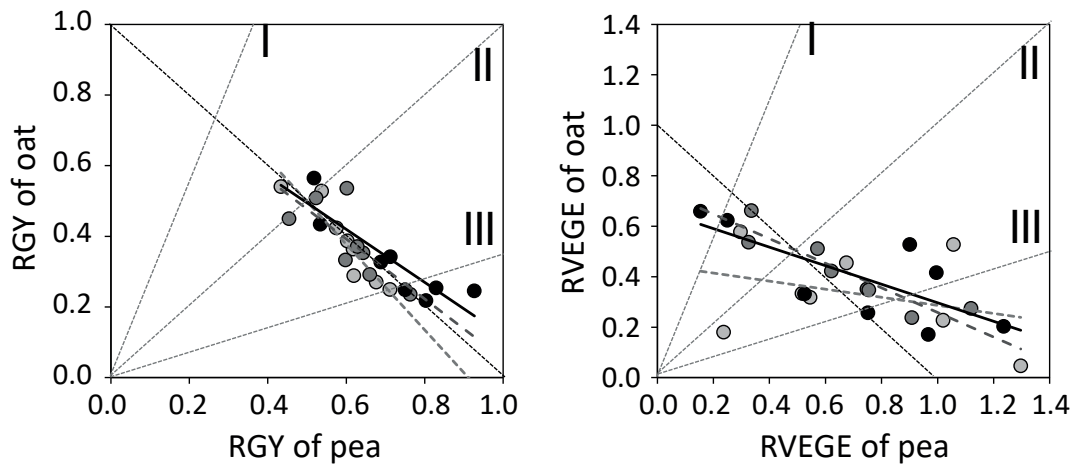

Fig. 3. Relative grain yield (RGY) and relative above-ground vegetative biomass (RVEGE) of pea cultivars and oat when intercropped. Light grey circle and dashed line indicates the pea cultivar Hulda ( $r=-0.93, p<0.001$ for RGY; $r=-0.34, p=0.42$ for RVEGE), grey Karita $(r=-0.74, p=0.03$ for RGY; $r=-0.92, p<0.001$ for RVEGE) and dark grey circle with solid line Perttu $(r=-0.89, p<0.01$ for RGY; $r=-0.74, p=0.03$ for RVEGE). The line from the upper left to the lower right corner indicated LER equaling one. The additional line with Roman numeral I indicates that, e.g., RGY in oat is three times higher than that in pea, II that RGY in oat and pea are equal, and III the inverse relationship of $\mathrm{I}$. 
Typically RGY of pea cultivars Hulda and Karita range from equal to less than three times that of oat, while in half of the experiments RGY in Perttu was more than three times higher than that in oat. On the other hand, RVEGE scattered more than RGY depending on experiment and cultivar. Contrary to RGY, in a couple of experiments RVEGE in oat was even two to four times higher than RVEGE of pea cultivars, but such poor performance of pea compared to oat always resulted in $L_{\text {vege }}<1$. In the case that RVEGE for pea was equal or higher in pea cultivars

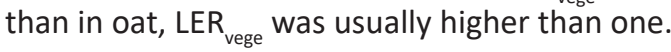

When characterizing traits of pea cultivars that contributed to the recorded variation in LER $_{\text {yield }}$, no such a trait, exhibiting a linear relationship with LER $_{\text {yield }}$ in all pea cultivars, was found. Pea cultivar $\times$ experiment interaction was significant for pea and oat GY $(p<0.0001)$. Grain yield of intercropped pea cultivar Karita associated negatively with LER yield $(F i g .4)$. Perttu again was the only cultivar, for which LER $_{\text {yield }}$ was $>1$ when its GY was higher than the mean GY of all pea cultivars. When intercropped with the cultivar Hulda, the higher the GY in oat, the higher was

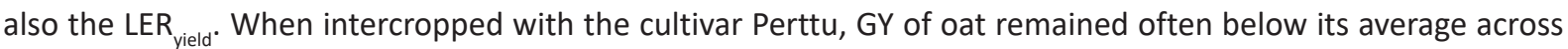
all experiments.
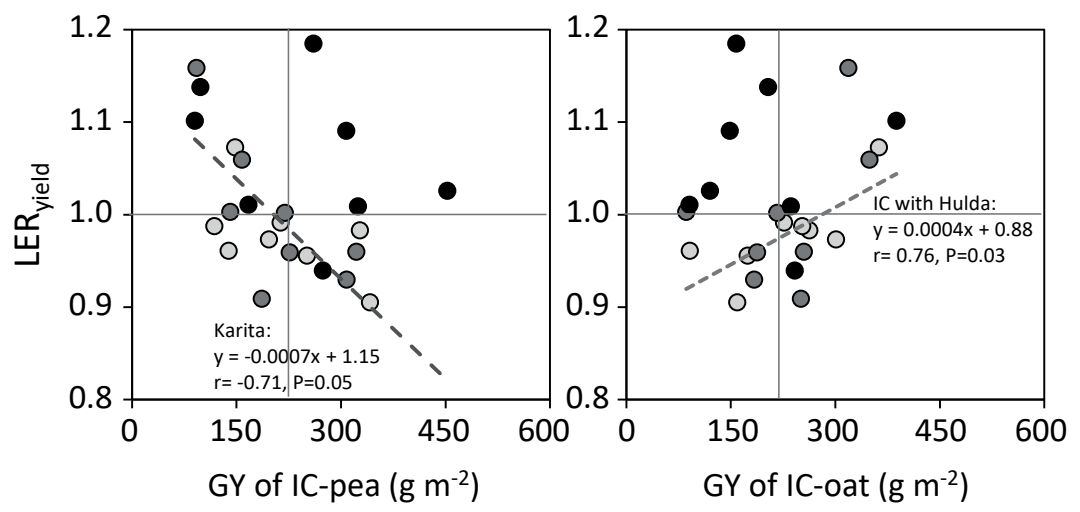

Fig. 4. Scatter diagram of grain yield (GY) and LER $\mathrm{vield}_{\text {of }}$ of pea and oat when intercropped. Vertical line indicates mean across all experiments and pea cultivars. Light grey circle and dashed line indicates the pea cultivar Hulda, grey Karita and dark grey circle Perttu.

Pea cultivar $\times$ experiment interaction was significant for GNO in pea $(p<0.0001)$ and oat $(p=0.018)$. As GNO is the main yield component contributing to $G Y$, the associations between GNO and LER $_{\text {yield }}$ were quite consistent with those recorded for GY. The higher the GNO per square meter for intercropped pea cultivars Hulda and Karita, while

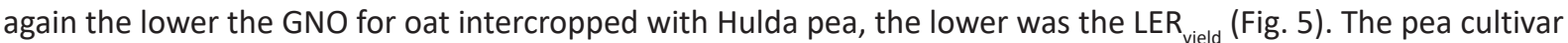
Perttu, however, differed from Hulda and/or Karita again, as experiments in which GNO was above average in Perttu had usually LER $_{\text {yield }}>1$, though without exhibiting any significant linear association between them. These findings on GY and GNO also agreed with the number of pods per square meter in intercropped pea (Fig. 6), where significant pea cultivar $\times$ experiment interaction was apparent as well $(p<0.0001)$.
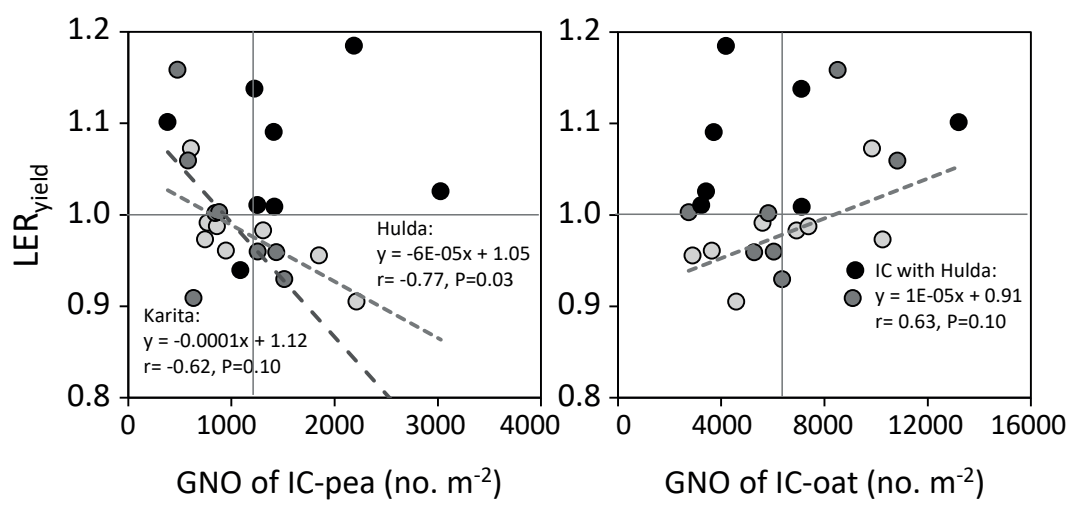

Fig. 5. Scatter diagram of grain number (GNO) and LER ${ }_{\text {yield }}$ of pea and oat when intercropped. Vertical line indicates mean across all experiments and pea cultivars. Light grey circle and dashed line indicates the pea cultivar Hulda, grey Karita and dark grey circle Perttu. 


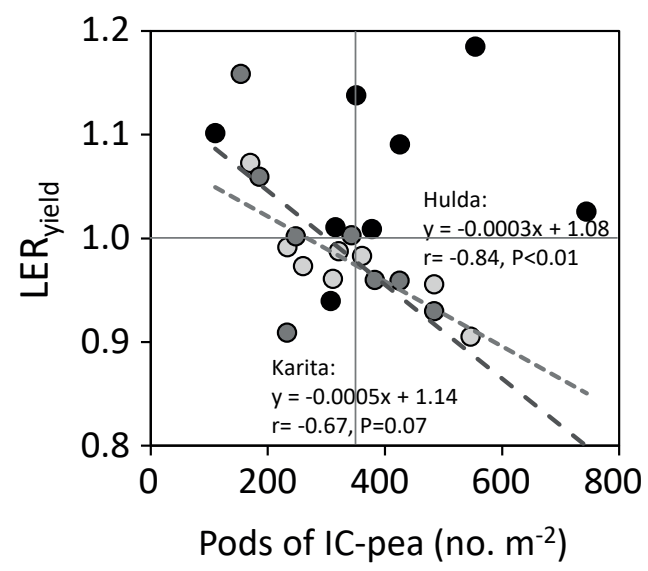

Fig. 6. Scatter diagram of number of pods per square meter and LER $_{\text {yield }}$ of pea cultivars when intercropped with oat. Vertical line indicates the mean across all experiments and pea cultivars. Light grey circle and dashed line indicates the pea cultivar Hulda, grey Karita and dark grey circle Perttu.

As better $\mathrm{N}$ acquisition is one of the highly valued ecosystem services provided by pea when intercropped with a non- $\mathrm{N}$-fixing crop, $\mathrm{N}$ content in the harvested yield was compared to supplied $\mathrm{N}$ fertilizer rate $\left(\mathrm{N}_{\text {ratio }}\right)$ in pure pea and oat stands and in their intercrops. Pea cultivar $\times$ experiment $(p=0.001)$ interaction was significant for $N_{\text {ratio }}$ and it was apparent that the range in $\mathrm{N}_{\text {ratio }}$ was high depending on the experiment, but also pea cultivar (Fig. 7).
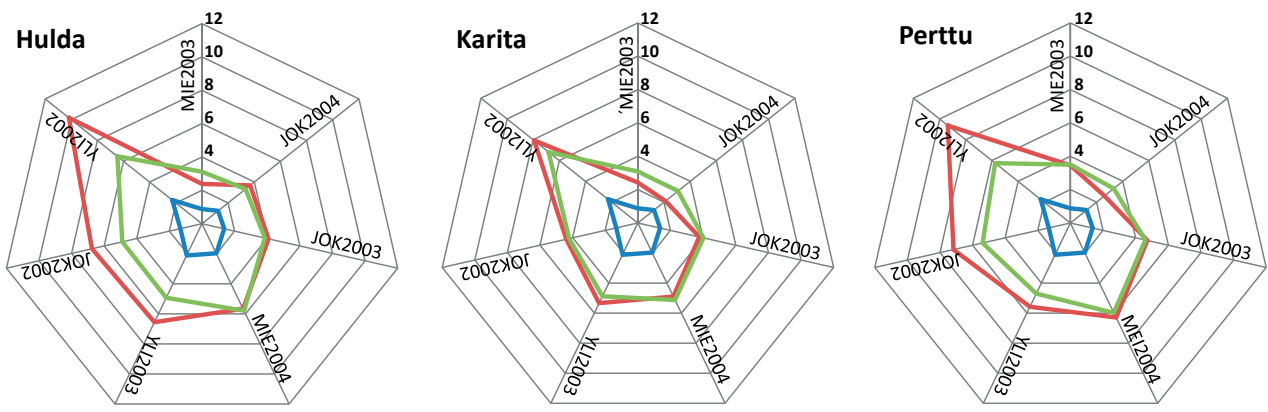

Fig. 7. Total amount of $\mathrm{N}$ removed with harvested yield compared to the applied $\mathrm{N}$ fertilizer rate $\left(\mathrm{N}_{\text {ratio }}\right)$ in pure oat stand (blue line), pure pea stand (red line) and pea-oat intercrop (green) in seven experiments (JOK, Jokioinen; MIE, Mietoinen; YLI, Ylistaro).

The cultivar Karita clearly had a lower $\mathrm{N}_{\text {ratio }}$ than Perttu and Hulda, especially when grown in a pure stand, and the difference in $\mathrm{N}_{\text {ratio }}$ for sole crop and intercrop was marginal compared to that for Hulda and Perttu. As $\mathrm{N}_{\text {ratio }}$ in a pure pea stand ranged from $\geq 3$ to up to $\sim 10$ in Hulda and Perttu, for Karita the $\mathrm{N}_{\text {ratio }}$ was $2-8$. Pure stand $\mathrm{N}_{\text {ratio }}$ for Karita was systematically lower than that for Hulda and Perttu in all experiments. Differences between pea cultivars in $\mathrm{N}_{\text {ratio }}$ of pea-oat intercrop were marginal and ranged mostly from three to seven depending on the experiment without exhibiting any systematic differences between pea cultivars. For a pure oat stand the $\mathrm{N}_{\text {ratio }}$ was much lower (0.9-2.3) than for any pea cultivar, which revealed that also pure oat stands were always able to retrieve all applied $\mathrm{N}$ or even more.

\section{Discussion}

Pea cultivars performed differently when intercropped with oat, but also growing conditions had a marked impact as they explained some $32 \%$ of the variation in LER $_{\text {yield }}$ and even $87 \%$ in intercropped GYs. Recorded variation both in timing and duration of phenological events like flowering in pea, panicle emergence in oat, and maturation of plant stands, depending on pea cultivar, location and year were attributable to highly variable weather conditions during the study period. Fukai and Trenbath (1993) emphasized that intercrops tend to be most 
successful in the case that their companion crops differ in growth duration and timing of main yield determination processes, which then also means timing of resource requirements. Different timing of phenological events also improves resilience against weather constraints and variability (Peltonen-Sainio et al. 2016a). Interestingly, panicle emergence in oat and onset of flowering in pea - and thereby, timing of grain set and filling - did not overlap. This may facilitate complementarity between oat and pea as companions in intercrops. For example, risk of drought episodes - often with coinciding elevated temperatures - is particularly high in early summer, after which it diminishes (Peltonen-Sainio et al. 2016a, Peltonen-Sainio et al. 2016b, Peltonen-Sainio et al. 2016c): in years when drought occurs, oat yields are at higher risk than for pea, as elevated temperatures interfere with yield formation of oat, but favors that in pea (Peltonen-Sainio et al. 2011). As we found substantial variation in accumulation of precipitation and temperature across years and locations, it is apparent that the recorded variation in onset and duration of critical phenophases exposed companion crops to harmful and/or advantageous weather events differently. This explains the recorded variation in RGY of intercropped oat and pea cultivars and ultimately their LER

Selecting appropriate cultivars for intercropping is the key measure when aiming at benefits of yield and resilience (Fukai 1993). Especially, choice of pea cultivar as a companion for intercropping with cereal is more critical than choice of cereal cultivar per se (Hauggaard-Nielsen and Jensen 2001). In our experiments, share of oat in an intercrop did not contribute to recorded variation in LER yield $_{\text {and }}$ antercropped GYs and hence, it was not considered further. The pea cultivar interacted with year and location, which all substantially contributed to the record-

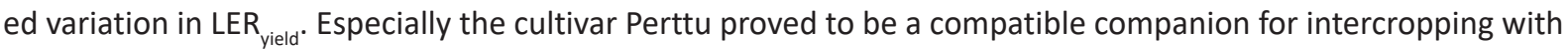
oat as systematic yield advantage was gained: mean LER-value was 1.06 across all the experiments and it was $<1$ only once. Intercropping with Karita did not result in yield advantage over the sole crop yields as LER averaged 1.00 , whereas Hulda was an incompatible companion for oat with its mean LER of 0.98 that exceeded one in only one experiment.

It is likely that the success of Perttu as a companion for oat in intercrops is attributable to its flexibility in building the yield through a variable combination of yield components rather than being outperforming in intercrops due to some single superior trait(s). Such flexibility likely generates resilience against weather variability that is typical for northern European conditions, as could be seen as high LER $R_{\text {grain }}$. The recorded superiority of the pea cultivar Perttu in intercrops with oat is likely attributable to timing and duration of critical growth processes, as suggested to be essential for successful companionship in intercrops by (Fukai and Trenbath 1993). Perttu was characterized as having the longest duration of flowering with the latest ending date. This may exhibit even a substantial risk for yield loss in the extremely short growing season of the northern Europe (Peltonen-Sainio and Niemi 2012), where early maturity is advantageous. However, GY of Perttu was successfully accomplished likely due to a high number of small grains contrary to large-grained Hulda and Karita cultivars.

In general, yield components did not necessarily vary less in Perttu than other pea cultivars. Perttu was, however, successful in overcompensating decline in oat RGY, contrary to Hulda (Fig. 3) when the method introduced by (Monzon et al. 2014) was applied. However, none of the measured yield components associated with LER yield $_{\text {for }}$ Perttu, suggesting compensation ability between them. Opposite to this, when Karita and/or Hulda produced higher grain yield and number of grains and pods per square meter when intercropped with oat, LER yield $_{\text {tended }}$ to decline. When oat again was successful in producing high GY and GNO, LER yield increased especially in Hulda.

Even though Perttu differed from other pea cultivars by having superior LER vield $_{\text {w }}$ when intercropped with oat, the same was not true for above-ground vegetative biomass. In fact, it seemed that especially Hulda had the capacity to invest resources in vegetative growth (RVEGE $>1.0)$ in the case that oat underperformed as its companion. However, such capacity to invest in vegetative growth did not associate with better capacity to compensate for low RGY in oat in an intercrop (Fig. 3) as Perttu did. Perttu is a pea cultivar that has been particularly - and according to our findings also successfully - bred for intercropping, though its potential has not been realized at farm scale in Finland. It has been found to be a valuable intercrop component also for organic farming (Markku Niskanen, personal communication 5 March 2017).

Despite the highly variable success of pea-oat intercrops in these experiments, except for the clearly successful oat and Perttu pea intercrops, it was evident that pea donated $N$ to oat (data not shown). For pea cultivars $N_{\text {ratio }}$ in a pure pea stand ranged from two to up to 10 , for a pure oat stand from one to two, and for a pea-oat intercrop from three to seven. All these results indicate that intercrops were successful in $\mathrm{N}$-fixation also when they underperformed considering RGY and $L E R_{\text {yield }}$. 
In conclusion, intercropping is often considered to be feasible for the farmer only when it provides yield advantage $\left(\mathrm{LER}_{\text {yield }}>1.00\right)$ compared to pure stands of the companion crops. The pea cultivar Perttu proved to be a compatible companion crop for oat with its average LER $_{\text {vield }}$ of 1.06 across all experiments. It was concluded that the success of Perttu as a companion for oat in intercrops is likely attributable to its flexibility in building yield through a variable combination of yield components rather than being outperformed due to some single superior traits. Such flexibility likely generates resilience against weather variability that is typical for northern European conditions to sustain LER $_{\text {yield }}$ consistently $>1$.

\section{Acknowledgements}

The work was financed by the Finnish Ministry of Agriculture and Forestry and MTT Agrifood Research Finland (since 1.1.2015 Natural Resources Institute Finland, Luke) as a part of consortium projects entitled Domestic protein from pea (KOVAHERNE) and Improving Resilience to Climate Change and Variation Induced Risks in Agriculture (ILMAPUSKURI). The authors are grateful to all the technicians who assisted in research activities, especially Arto Timonen.

\section{References}

Barker, S. \& Dennett, M.D. 2013. Effect of density, cultivar and irrigation on spring sown monocrops and intercrops of wheat (Triticum aestivum L.) and faba beans. European Journal of Agronomy 51: 108-116. https://doi.org/10.1016/j.eja.2013.08.001

Brooker, R.W., Bennett, A.E., Cong, W.-F., Daniell, T.J., George, T.S., Hallett, P.D., Hawes, C., lennetta, P.P.M., Jones, H.G., Karley, A.J., Li, L., McKenzie, B.M., Pakeman, R.J., Paterson, E., Schöb, C., Shen, J., Squire, G., Watson, C.A., Zhang, C., Zhang, F., Zhang, J. \& White, P. 2015. Improving intercropping: a synthesis of research in agronomy, plant physiology and ecology. New Phytologist 206: 107-117. https://doi.org/10.1111/nph.13132

Corre-Hellou, G., Brisson, N., Launay, M., Fustec, J. \& Crozat, Y. 2007. Effect of root depth penetration on soil nitrogen competitive interactions and dry matter production in pea-barley intercrops given different soil nitrogen supplies. Field Crops Research 103: 76-85. https://doi.org/10.1016/j.fcr.2007.04.008

Cousin, R. 1997. Peas (Pisum sativum L.). Field Crops Research 53: 111-130. https://doi.org/10.1016/S0378-4290(97)00026-9

Fukai, S. 1993. Intercropping - bases of productivity. Field Crops Research 34: 239-245. https://doi.org/10.1016/0378-4290(93) 90116-5

Fukai, S. \& Trenbath, B.R. 1993. Processes determining intercrop productivity and yields of component crops. Field Crops Research 34: 247-271. https://doi.org/10.1016/0378-4290(93)90117-6

Hauggaard-Nielsen, H., Andersen, M.K., Jørnsgaard, B. \& Jensen, E.S. 2006. Density and relative frequency effects on competitive interactions and resource use in pea-barley intercrops. Field Crops Research 95: 256-267. https://doi.org/10.1016/j.fcr.2005.03.003

Hauggaard-Nielsen, H. \& Jensen, E.S. 2001. Evaluating pea and barley cultivars for complementarity in intercropping at different levels of soil N availability. Field Crops Research 72: 185-196. https://doi.org/10.1016/S0378-4290(01)00176-9

Huusela-Veistola, E. \& Jauhiainen, L. 2006. Expansion of pea cropping increases the risk of pea moth (Cydia nigricana; Lep., Tortricidae) infestation. Journal of Applied Entomology 130: 142-149. https://doi.org/10.1111/j.1439-0418.2006.01047.x

Kenward, M.G. \& Roger, J.H. 1997. Small sample inference for fixed effects from restricted maximum likelihood. Biometrics 53 : 983-997. https://doi.org/10.2307/2533558

Kontturi, M., Laine, A., Niskanen, M., Hurme, T., Hyövelä, M. \& Peltonen-Sainio, P. 2011. Pea-oat intercrops to sustain lodging resistance and yield formation in northern European conditions. Acta Agriculturae Scandinavica: Section B, Soil \& Plant Science 61: 612-621.

Lauk, R. \& Lauk, E. 2008. Pea-oat intercrops are superior to pea-wheat and pea-barley intercrops. Acta Agriculturae Scandinavica: Section B, Soil \& Plant Science 58: 139-144.

Monzon, J.P., Mercau, J.L., Andrade, J.F., Caviglia, O.P., Cerrudo, A.G., Cirilo, A.G., Vega, C.R.C., Andrade, F.H. \& Calvi-o, P.A. 2014. Maize-soybean intensification alternatives for the Pampas. Field Crops Research 162: 48-59. https://doi.org/10.1016/j. fcr.2014.03.012

Peltonen-Sainio, P., Hannukkala, A., Huusela-Veistola, E., Voutila, L., Niemi, J., Valaja, J., Jauhiainen, L. \& Hakala, K. 2013. Potential and realities of enhancing rapeseed- and grain legume-based protein production in a northern climate. Journal of Agricultural Science 151: 303-321. https://doi.org/10.1017/S002185961200038X

Peltonen-Sainio, P., Jauhiainen, L. \& Hakala, K. 2011. Crop responses to temperature and precipitation according to longterm multi-location trials at high-latitude conditions. The Journal of Agricultural Science 149: 49-62. https://doi.org/10.1017/ S0021859610000791

Peltonen-Sainio, P., Jauhiainen, L., Hakala, K. \& Ojanen, H. 2009. Climate change and prolongation of growing season : changes in regional for field crop production in Finland. Agricultural and Food Science 18: 171-190. https://doi.org/10.2137/145960609790059479

Peltonen-Sainio, P., Jauhiainen, L. \& Lehtonen, H. 2016a. Land use, yield and quality changes of minor field crops: Is there superseded potential to be reinvented in northern Europe? Plos One. https://doi.org/10.1371/journal.pone.0166403 
Peltonen-Sainio, P., Jauhiainen, L. \& Sorvali, J. 2017. Diversity of high-latitude agricultural landscapes and crop rotations: increased, decreased or back and forth? Agricultural Systems 154: 25-33. https://doi.org/10.1016/j.agsy.2017.02.011

Peltonen-Sainio, P. \& Niemi, J.K. 2012. Protein crop production at the northern margin of farming: To boost, or not to boost. Agricultural and Food Science 21: 370-383.

Peltonen-Sainio, P., Pirinen, P., Mäkelä, H.M., Hyvärinen, O., Huusela-Veistola, E., Ojanen, H. \& Venäläinen, A. 2016b. Spatial and temporal variation in weather events critical for boreal agriculture: I Elevated temperatures. Agricultural and Food Science 25: 44-56.

Peltonen-Sainio, P., Pirinen, P., Mäkelä, H.M., Ojanen, H. \& Venäläinen, A. 2016c. Spatial and temporal variation in weather events critical for boreal agriculture: II Precipitation. Agricultural and Food Science 25: 57-70.

Petersen, R.G. 1994. Agricultural Field Experiments - Design and Analyses. Marcel Dekker Inc., New York. 409 p.

Podgórska-Lesiak, M. \& Sobkowicz, P. 2013. Prevention of pea lodging by intercropping barley with peas at different nitrogen fertilization levels. Field Crops Research 149: 95-104. https://doi.org/10.1016/j.fcr.2013.04.023

Schoeny, A., Jumel, S., Rouault, F., Lemarchand, E. \& Tivoli, B. 2010. Effect and underlying mechanisms of pea-cereal intercropping on the epidemic development of ascochyta blight. European Journal of Plant Pathology 126: 317-331. https://doi.org/10.1007/ s10658-009-9548-6

Snaydon, R.W. 1991. Replacement or additive designs for competition studies? Journal of Applied Ecology 28: 930-946. https:// doi.org/10.2307/2404218

Soussana, J., Fereres, E., Long, S.P., Mohren, F.G.M.J., Pandya-Lorch, R., Peltonen-Sainio, P., Porter, J.R., Rosswall, T. \& Braun, J. 2012. A European science plan to sustainably increase food security under climate change. Global Change Biology 18: 3269-3271. https://doi.org/10.1111/j.1365-2486.2012.02746.x

Storkey, J., Döring, T., Baddeley, J., Collins, R., Roderick, S., Jones, H. \& Watson, C. 2015. Engineering a plant community to deliver multiple ecosystem services. Ecological Applications: A Publication Of The Ecological Society Of America 25: 1034-1043.

Tecator 1987. Determination of Kjeldahl nitrogen content with Kjeltec System 1026. Application Note 86/87: 1-9.

Verret, V., Gardarin, A., Pelzer, E., Médiène, S., Makowski, D. \& Valantin-Morison, M. 2017. Can legume companion plants control weeds without decreasing crop yield? A meta-analysis. Field Crops Research 204:158-168. https://doi.org/10.1016/j.fcr.2017.01.010

Willey, R.W. 1990. Resource use in intercropping systems. Agricultural Water Management 28: 930-946. https://doi. org/10.1016/0378-3774(90)90069-B 